\title{
The Impact of Epicatechin on Human Cognition: The Role of Cerebral Blood Flow
}

\author{
Crystal F. Haskell-Ramsay ${ }^{1, *(1)}$, Jeroen Schmitt ${ }^{2}$ (i) and Lucas Actis-Goretta ${ }^{3}$ \\ 1 Department of Psychology, Northumbria University, Newcastle upon Tyne NE1 8ST, UK \\ 2 Nestlé Research Centre, Route du Jorat 94, 1000 Lausanne, Switzerland; Jeroen.Schmitt@rdls.nestle.com \\ 3 Nestlé Research Centre, 21 Biopolis Road, Singapore 138567, Singapore; Lucas.ActisGoretta@rdsg.nestle.com \\ * Correspondence: crystal.haskell-ramsay@northumbria.ac.uk; Tel.: +44-191-227-4875
}

Received: 5 July 2018; Accepted: 24 July 2018; Published: 27 July 2018

check for updates

\begin{abstract}
Epicatechin is a monomeric flavanol found in food sources such as tea, apples, berries and cocoa. A number of large-scale epidemiological studies have demonstrated an association between the consumption of these foods and cognitive function, as well as improved blood flow. The aim of this review is to summarise the evidence from intervention studies to clarify the effect of epicatechin on cognition and to consider the role of increased cerebral blood flow as a mechanism for any effects. The effects of epicatechin as consumed in cocoa are, therefore, reviewed here as this represents the only dietary source where it is purported to be the major active component. Our main findings are that a) the positive modulation of tasks that involve memory, executive function and processing speed in older adults; $b$ ) the cognitive benefits are more often shown in studies containing more than $50 \mathrm{mg}$ epicatechin/day; and c) all studies with a duration of 28 days or longer in populations $>50$ years old demonstrate a cognitive improvement. However, as highlighted by this review, it is not currently possible to attribute effects solely to epicatechin without consideration of synergies. In order to overcome this issue, further studies examining the cognitive effects of epicatechin in isolation are required. The role of cerebral blood flow also requires further investigation through simultaneous measurement alongside cognitive function.
\end{abstract}

Keywords: epicatechin; cocoa; cognition; cognitive; cerebral blood flow; mood; phenolic; polyphenol; phytochemical

\section{Introduction}

Flavanols are a subclass of the bioactive compounds, flavonoids, which can be further sub-divided into monomeric flavan-3-ols and their oligomeric/polymeric counterparts, procyanidins. Epicatechin (see Figure 1), along with catechin, is a monomeric flavan-3-ol, which is abundant in food sources such as tea, apples, berries, and particularly cocoa. A number of large-scale epidemiological studies have demonstrated a link between the consumption of these epicatechin-rich foods and cognitive function. For instance, the Paquid longitudinal study demonstrated that the relative risk of dementia was significantly lower for those in the two highest tertiles of flavonoid consumption, compared to those in the lowest tertile when followed up 5 years later [1]. In addition, analysis of neuropsychological function (Benton's Visual Retention Test, Isaacs Set Test, Mini-Mental State Examination (MMSE)) at initial assessment of flavonoid intake (including flavanols), revealed a significant positive association between flavonoid consumption and task performance. An inverse relationship between intake and cognitive decline over the 10-year follow up was also demonstrated, whereby those in the highest two quartiles of flavonoid intake had less cognitive decline than those in the lowest quartile [2]. Other studies have provided data on specific sources of flavonoid. In a cross-sectional study of 1003 community-dwelling Japanese adults aged 70 years and above, Kuriyama et al. [3] 
demonstrated a significant inverse relationship between catechin-rich green tea consumption and cognitive impairment, as measured by MMSE, which was not observed for fermented black or semi-fermented oolong tea, or coffee. The role of flavonoids in this relationship is questioned by data from the Singapore Longitudinal Ageing Studies cohort showing a significant negative relationship between cognitive decline (MMSE) and black and oolong tea, but not green tea, in 2194 Chinese community-dwelling adults aged over 55 [4]. However, further analysis of a sub-sample of this cohort in a cross-sectional design employing a range of cognitive tasks showed that tea consumption was associated with the better performance across tasks, irrespective of whether fermented (black/oolong) or unfermented (green) [5]. Similarly, in the Norwegian Hordaland Health Study (HUSK), 2031 elderly (70-74 years) tea drinkers performed better in 4 out of 6 cognitive tests as compared to non-tea drinkers; wine drinkers also showed significantly better performance across all six tests versus non-wine drinkers, with this effect levelling off at $100 \mathrm{~mL} /$ day; and consumers of chocolate performed significantly better than non-consumers in 5 out of 6 cognitive tests, with a plateau in increased performance at $10 \mathrm{~g}$ per day [6].<smiles>Oc1cc(O)c2c(c1)O[C@H](c1ccc(O)c(O)c1)[C@H](O)C2</smiles>

Figure 1. The chemical structure of (-)-epicatechin.

Epidemiological studies suffer a number of well-documented problems, such as the difficulty in attributing cause and effect and uncontrolled confounds. However, an additional issue with the cohort data described above is that it does not allow conclusions regarding the role of epicatechin in these effects. In the case of wine consumption, findings are particularly difficult to interpret in relation to flavonoid content due to studies showing positive effects on cognition of moderate alcohol intake [7]. Similarly, as tea also contains caffeine and the amino acid 1-theanine, it is difficult to determine the specific contribution of flavonoids to this relationship; and, in the case of green tea, the effects are often attributed to epigallocatechin-3-gallate (EGCG), rather than epicatechin. The limitations of epidemiological data require that in order to reliably assess the impact of epicatechin on the brain, it is necessary to consider data collected in randomised controlled trials. However, there are currently no published intervention trials examining the effects of isolated epicatechin on human cognition. Therefore, as cocoa represents the only dietary source where epicatechin is purported to be the major active component, this paper will review human randomised controlled trials exploring the role of epicatechin administered in cocoa on cognition. The potential mechanisms for the effects of epicatechin-rich cocoa on cognition will then be discussed with a particular focus on the role of cerebral blood flow.

\section{Cognition Intervention Studies}

In the first intervention study to assess the effects of epicatechin-rich cocoa on cognition, the impact of 5 days' supplementation with $172 \mathrm{mg}$ of cocoa flavanols (CF) (31 mg epicatechin) on letter pair switching performance was assessed. No effects were observed in healthy young females when compared to a matched control [8]. It is possible that the dose employed in this study was insufficient to produce behavioural effects, but another suggestion is that the healthy young participants were performing close to ceiling and benefits were therefore unlikely to be observed. This latter suggestion is supported by the demonstration of significant improvements to the performance of an intense 60-min Cognitive Demand Battery (CDB) in healthy young adults. Improvements to executive 
function and attenuation of mental fatigue increases induced by the demanding tasks were observed at 90 min post-administration of 520 and $994 \mathrm{mg}$ of CF ( 94 and $184 \mathrm{mg}$ epicatechin respectively) when compared to a control matched for macronutrient, mineral, caffeine and theobromine content [9]. Improvements to sustained [10] and selective attention [11] have been demonstrated in more recent studies following acute supplementation with CF. However, one study failed to find effects on a single 5-min Stroop task following $900 \mathrm{mg}$ of CF [12], again potentially indicating issues with ceiling effects. The importance of task demands/fatigue is further highlighted by evidence showing that CF (447 mg epicatechin) can offset the negative effects of sleep deprivation on a working memory task at $90 \mathrm{~min}$ post-consumption in women [13]. Improvements to visual contrast sensitivity (as assessed by reading numbers that became progressively more similar in luminance to their background), time to detect motion direction, and visual-spatial memory were also shown in 18- to 25-year-olds, 90 min following acute consumption of dark chocolate as compared to white chocolate [14]. However, the use of a control that was not matched for methylxanthine or macro/micronutrient content makes it impossible to attribute the effects to phenolic compounds. This issue is overcome when comparing the effects of a cocoa tablet (3058 mg Theobroma cacao seed extract containing $250 \mathrm{mg}$ CF) to cellulose in 18-to 40-year-olds [15]. Lower mental fatigue ratings prior to a shortened 30-min version of the CDB described above, as well as a greater number of serial sevens subtractions during the first repetition of the task were observed in the cocoa group when measured at $3 \mathrm{~h}$ post-tablet consumption. Stress ratings following 30 days' supplementation were also higher following cocoa than placebo, an effect that is difficult to explain. It should be noted that each of the significant findings presented was the result of individual comparisons of the data at each time point. Therefore, given the isolated nature of these effects and the statistical approach adopted, it would be unwise to over-interpret these findings.

The finding of higher stress levels is also in contrast to findings from Pase et al. [16] showing increased calm and content ratings following CF supplementation. Cognitive and mood effects were assessed acutely and following 30 days' supplementation in 40- to 65-year-olds using the standard 20-min Cognitive Drug Research (CDR) battery employed in numerous dietary intervention studies (e.g., [17,18]) and Bond-Lader mood scales [19]. Neither 250 nor $500 \mathrm{mg}$ of CF (25 and $50 \mathrm{mg}$ of epicatechin, respectively) impacted significantly on cognition or mood when measured acutely at 1, 2.5 and $4 \mathrm{~h}$; however, increases in calm and content ratings were observed following 30 days' supplementation with $500 \mathrm{mg}$ of $\mathrm{CF}$, which the authors suggest may be due to action on $\mathrm{GABA}_{\mathrm{A}}$ receptors. Neurocognitive data from the same study showed no effects on a spatial working memory task assessed at baseline and following the 30-day supplementation. Steady State Visually Evoked Potentials (SSVEPs) recorded during task performance using Steady State probe Topography (SST), a form of electrophysiological brain imaging, revealed, perhaps surprisingly, that the pattern of posterior-parietal SSVEP amplitude in the $250 \mathrm{mg}$ CF group, and to a lesser extent the $500 \mathrm{mg}$ group, was significantly lower than the pattern observed following the control. Latency was also decreased in the same region following both the 250 and $500 \mathrm{mg}$ CF interventions, indicative of increased neural processing speed [20]. In light of the lack of effects on cognition and the reduction in latency, it is suggested by the authors that this decrease in amplitude may reflect an increase in neural efficiency, whereby participants are able to perform at the same level with reduced activation. This assertion is supported by previous data showing a positive association between increased posterior-parietal activation and task difficulty [21]. It is interesting to note that this potential increase in neural efficiency seen following $250 \mathrm{mg}$ is not accompanied by the modulation of mood demonstrated by the $500 \mathrm{mg}$ dose, as presented in Pase et al. [16]. It has been suggested that a longer supplementation may be required to see robust improvements in cognition. Indeed, Brickman et al. [22] demonstrated that 12 weeks' supplementation with $900 \mathrm{mg}$ CF (138 mg epicatechin) led to participants in the high CF group responding 630 milliseconds faster than those consuming a matched low CF control on a Modified-Benton test, developed to localise the function to the dentate gyrus area of the hippocampus. This difference in reaction time equates to around three decades of ageing and was evinced as a slowing of responses from baseline to study end in the control group, as well as a faster response in the high 
$\mathrm{CF}$ group. The effects on reaction time were inversely related to cerebral blood volume changes in the dentate gyrus. These data are extremely exciting and provide an excellent basis for further study.

In addition to the longer intervention employed, Brickman et al. [22] also explored the effects in a slightly older cohort (50-69 years) and it may be that age played an important role in these effects. In the first study of the cognitive effects of cocoa in elderly adults, Crews et al. [23] failed to find any effects of $805 \mathrm{mg}$ of CF ( $35 \mathrm{mg}$ epicatechin) supplemented to over 60-year-olds (mean 68.7 years) for 6 weeks. However, the treatments were not matched for methylxanthine or micronutrient content and, importantly, the carbohydrate and energy levels were more than doubled in the control as a consequence of the use of sugar rather than the sweetener used in the cocoa condition. In addition, the low levels of epicatechin could explain the lack of cognitive effects. It is, therefore, difficult to interpret these null findings in relation to flavan-3-ols. Similarly, Sorond et al. [24] failed to find improvements to MMSE or Trail Making Tasks (TMT) A and B when measured at $24 \mathrm{~h}$ and 4 weeks following $1218 \mathrm{mg}$ of CF (219 mg epicatechin) per day in older adults enrolled on the basis of hypertension or type II diabetes. However, significant improvements to global cognition and increases in brain-derived neurotrophic factor (BDNF) have been observed following 28 days supplementation with $494 \mathrm{mg}$ of CF (89 mg epicatechin) in healthy elderly [25]. Furthermore, Desideri et al. [26] demonstrated improvements to cognition in elderly adults (65+ years) with Mild Cognitive Impairment (MCI) following 8 weeks' supplementation. Compared to control, 520 and $994 \mathrm{mg}$ of CF (95 and $185 \mathrm{mg}$ epicatechin) led to faster completion times on TMT A and B and $994 \mathrm{mg}$ also led to significantly improved verbal fluency performance compared to the control. Reduced insulin resistance (IR) as a consequence of CF consumption was found to explain $\sim 40 \%$ of composite $z$ score variability. In a replication of this work in healthy elderly adults, Mastroiacovo et al. [27] observed identical results to those shown in MCI with the exception that IR explained $\sim 17 \%$ of composite $z$ score variability. In both studies, there were no significant effects on MMSE, highlighting the lack of sensitivity of this measure to detect small changes in cognition over a short time period. It is currently unclear whether the lack of improvements reported by Sorond et al. [24], despite improvements on the same tasks in Desideri [26] and Mastroiacovo [27], relates to the shorter length of intervention, the population studied, or the high dose employed, and these factors all require further investigation. Similarly, the only study of acute effects in older adults failed to detect any improvement to cognition [28], a finding which may relate to the low dose of epicatechin (25 $\mathrm{mg}$ and $49 \mathrm{mg}$ ), small sample size or insensitive task selection.

Seven out of nine studies that focused on the effects of a single dose of epicatechin-rich cocoa explored effects in young populations ( $<40$ years). Of these, six showed positive effects upon cognition [9-11,13-15]. The only study to fail to show acute effects in a young population employed a small sample size $(n=12)$ and a single 2-part task lasting only $5 \mathrm{~min}$ [12]. Of the two studies in older adults ( $>40$ years), one employed a small sample size [28] and the other explored effects in 40-65 years [16] who may be a particularly difficult age group to detect effects in due to the presence of undiagnosed underlying conditions with the potential to impact the findings. Of the 10 studies to explore the effects of repeated administration, 4 showed positive effects on cognition. Those studies that failed to find effects $[8,15,16,20,23,24]$ tended to employ a shorter intervention period ( 5 days to 6 weeks), whilst positive effects were observed when administration continued for longer $(8-12$ weeks) $[22,26,27]$. One notable exception to this is the finding of a global improvement to cognition in older adults following 28 days' supplementation [25]. This may be due to the combining of outcomes to increase the power or the use of a crossover design to minimise the impact of individual differences. Those studies showing a positive effect also employed a higher dose of epicatechin $(>50 \mathrm{mg}$ ) than those failing to show effects. One exception to this is a lack of effects following 30 days' supplementation with $219 \mathrm{mg}$ of epicatechin [24], these null findings may relate to the length of intervention or to the inclusion criteria of hypertension and/or type II diabetes.

See Table 1 for a summary of randomised controlled trials assessing the impact of cocoa on cognition. 
Table 1. Randomised controlled trials assessing the effects of cocoa on cognition.

\begin{tabular}{|c|c|c|c|c|c|}
\hline Reference & Sample & Design & Dose, Duration & Methods & Effects of Epicatechin \\
\hline Francis et al. (2006) [8] & $\begin{array}{c}n=16 \text { females } \\
(18-30 \text { years })\end{array}$ & RDBPC crossover & $\begin{array}{l}172 \mathrm{mg} \mathrm{CF} \text { (31 mg } \\
\text { epicatechin). Five days }\end{array}$ & Switch task; fMRI; HR (1.5 h PD) & $\begin{array}{l}\text { Increased BOLD response in the } \\
\text { dorsolateral prefrontal cortex, parietal } \\
\text { cortex and ACC. No effects on cognition. }\end{array}$ \\
\hline Scholey et al. (2010) [9] & $\begin{array}{c}n=30 \text { (18-35 years; } \\
\text { mean 22) }\end{array}$ & RDBPC crossover & $\begin{array}{l}520 \mathrm{mg} \mathrm{CF} ; 994 \mathrm{mg} \mathrm{CF} \\
\text { (94/184 mg epicatechin). } \\
\text { Acute }\end{array}$ & $\begin{array}{l}2 \text { serial subtraction tasks ( } 3 \text { and } 7 \text { s); RVIP; } \\
\text { mental fatigue; STAI-Y1 (1.5 h PD) }\end{array}$ & $\begin{array}{c}\text { Increased correct serial } 3 \text { subtractions; } \\
94 \mathrm{mg} \text { attenuated mental fatigue; } 184 \mathrm{mg} \\
\text { improved RVIP RT but increased serial } \\
7 \text { subtraction errors. }\end{array}$ \\
\hline Boolani et al. (2017) [10] & $\begin{array}{l}n=23(17 \text { male }) \\
\text { (mean } 20 \text { years) }\end{array}$ & RDBPC crossover & $\begin{array}{l}499 \mathrm{mg} \mathrm{CF} \text { (epicatechin } \\
\text { NK); } 499 \mathrm{mg} \text { CF+70 mg caff; } \\
66 \text { mg caff. Acute }\end{array}$ & $\begin{array}{l}\text { Serial subtractions ( } 3 \text { and } 7 \text { s); Bakan; CPT; } \\
\text { motivation; mood; salivary } \\
\text { methylxanthines (baseline and 22, } 60 \text { and } \\
98 \text { min PD) }\end{array}$ & $\begin{array}{l}\text { CF vs placebo: decreased Bakan RT and } \\
\text { FA. CF vs. CF + caff: decreased Bakan } \\
\text { correct and increased omission errors. CF + } \\
\text { caff vs. caff: decreased anxiety. }\end{array}$ \\
\hline Tsukamoto et al. (2018) [11] & $\begin{array}{c}n=10 \text { males } \\
\text { (mean } 23 \text { years) }\end{array}$ & RSBPC crossover & 563 mg CF (epicatechin NK) & $\begin{array}{c}\text { 2-part Stroop; Face-name matching; FAS; } \\
\text { mental fatigue; concentration; motivation: } \\
\text { HR; MAP; glucose; lactate (baseline and } \\
30 \text { and } 60 \mathrm{~min} \text { PD at rest and 100, } 130 \text { and } \\
160 \mathrm{~min} \text { PD after exercise) }\end{array}$ & Improved Stroop interference. \\
\hline Decroix et al. (2016) [12] & $\begin{array}{c}n=12 \text { male } \\
\text { (mean } 30 \text { years) }\end{array}$ & RDBPC crossover & $\begin{array}{l}900 \mathrm{mg} \mathrm{CF}(185 \mathrm{mg} \\
\text { epicatechin). Acute }\end{array}$ & $\begin{array}{c}\text { 2-part Stroop; NIRS; BDNF (baseline and } \\
95 \text { min PD at rest and } 145 \text { min PD } \\
\text { after exercise) }\end{array}$ & $\begin{array}{c}\text { Increased } \Delta \mathrm{HbO}_{2} \text { during word-colour } \\
\text { Stroop at rest. }\end{array}$ \\
\hline Grassi et al. (2016) [13] & $\begin{array}{l}n=32(16 \text { male }) \\
\text { (mean } 25 \text { years })\end{array}$ & RDBPC crossover & $\begin{array}{l}520 \mathrm{mg} \mathrm{CF} \text { (447 mg } \\
\text { epicatechin). Acute }\end{array}$ & $\begin{array}{l}\text { KSS; PVT; 2-back; FMD; BP; PWV (baseline } \\
\text { 'sleep' condition and } 90 \text { min PD in } \\
\text { 'deprivation' condition following } \\
\text { one-night total sleep deprivation) }\end{array}$ & $\begin{array}{l}\text { Preserved 2-back accuracy in women after } \\
\text { 'deprivation'. SBP, DBP and pulse pressure } \\
\text { lower after CF vs. control. Negative effects } \\
\text { of 'deprivation' on FMD and PWV } \\
\text { counteracted by CF. FMD correlated with } \\
\text { 2-back accuracy in 'sleep'. }\end{array}$ \\
\hline Field et al. (2011) [14] & $n=30$ (18-25 years) & RSBPC crossover & $\begin{array}{c}773 \mathrm{mg} \mathrm{CF} \\
\text { (epicatechin NK). Acute }\end{array}$ & $\begin{array}{c}\text { CS; motion coherence threshold; motion } \\
\text { integration time threshold; visual SWM; } \\
\text { CRT (2 h PD) }\end{array}$ & $\begin{array}{l}\text { Improved CS, improved WM accuracy and } \\
\text { speeded motion integration and CRT. }\end{array}$ \\
\hline Massee et al. (2015) [15] & $\begin{array}{c}n=40(18-40 \text { years, } \\
\text { mean } 24)\end{array}$ & RDBPC parallel groups & $\begin{array}{c}250 \mathrm{mg} \mathrm{CF} \text { (epicatechin NK). } \\
\text { Acute/30 days }\end{array}$ & $\begin{array}{l}\text { TCD of CCA, SUCCAB, CDB } \times 3 \text {, mental } \\
\text { fatigue and stress before and after CDB, } \\
\text { (baseline and } 2 \mathrm{~h} \text { acutely and at } 30 \text { days) }\end{array}$ & $\begin{array}{l}\text { Decrease in fatigue pre-CDB and increase } \\
\text { in sevens correct during the first repetition } \\
\text { acutely. Stress lower at } 30 \text { days in the } \\
\text { placebo group. }\end{array}$ \\
\hline Pase et al. (2013) [16] & $n=72(40-65$ years $)$ & RDBPC parallel groups & $\begin{array}{l}250 \mathrm{mg} \mathrm{CF} ; 500 \mathrm{mg} \\
\text { (25/50 mg epicatechin). } \\
\text { Acute/30 days }\end{array}$ & $\begin{array}{l}\text { Immediate WR; Simple RT; DV; Choice RT; } \\
\text { Tracking; Spatial WM; Numeric WM; } \\
\text { Delayed WR; Word Recognition; Picture } \\
\text { Recognition; Bond-Lader VAS (baseline, } 1 \text {, } \\
2.5 \text { and } 4 \text { h acutely and at } 30 \text { days) }\end{array}$ & Increased calm and content at 30 days. \\
\hline Camfield et al. (2011) [20] & $\begin{array}{c}n=63(40-65 \text { years; } \\
\text { mean } 52)\end{array}$ & RDBPC parallel groups & $\begin{array}{l}250 \mathrm{mg} \mathrm{CF} ; 500 \mathrm{mg} \mathrm{CF} \\
\text { (25/50 mg epicatechin). } \\
\text { Thirty days }\end{array}$ & SST-SSVEP; SWM (baseline and PD) & $\begin{array}{l}\text { Decreased SSVEP amplitude }(25 \mathrm{mg}) \text { and } \\
\text { increased latency }(25 \text { and } 50 \mathrm{mg}) \text { in } \\
\text { posterior parietal regions. }\end{array}$ \\
\hline
\end{tabular}


Table 1. Cont

\begin{tabular}{|c|c|c|c|c|c|}
\hline Reference & Sample & Design & Dose, Duration & Methods & Effects of Epicatechin \\
\hline Brickman et al. (2014) [22] & $n=37(50-69$ years $)$ & RDBPC parallel groups & $\begin{array}{c}900 \mathrm{mg} \mathrm{CF} \mathrm{(138} \mathrm{mg} \\
\text { epicatechin). Twelve weeks }\end{array}$ & $\begin{array}{l}\text { ModBent; CBV dentate gyrus (fMRI) } \\
\text { (baseline and PD) }\end{array}$ & $\begin{array}{l}\text { ModBent RT } 630 \mathrm{~ms} \text { faster in CF vs. } \\
\text { control. CBV enhanced in CF; a correlation } \\
\text { between change in cognition and CBV. }\end{array}$ \\
\hline Crews et al. (2008) [23] & $\begin{array}{c}n=90(\geq 60 \text { years; } \\
\text { mean 69) MCI }(\geq 24 \\
\text { MMSE })\end{array}$ & RDBPC parallel groups & $\begin{array}{l}755 \text { mg CF (epicatechin NK). } \\
\text { Six weeks }\end{array}$ & $\begin{array}{l}\text { BSRT; WMS-III Faces I and II; TMT; Stroop; } \\
\text { WAIS-III DSST; total cholesterol (HDL, } \\
\text { LDL, VLDL); triacylglycerol; C-reactive } \\
\text { protein (baseline and } 6 \text { weeks). A-DACL } \\
\text { General Activation; SBP; DBP; HR } \\
\text { (baseline, and at } 2 \mathrm{~h} \text { PD at } 3 \text { and } 6 \text { weeks) }\end{array}$ & $\begin{array}{l}\text { No positive effects. CF increased HR } \\
\text { ( } 3 \text { and } 6 \text { weeks). }\end{array}$ \\
\hline Sorond et al. (2013) [24] & $\begin{array}{c}n=60 \text { (mean } 73 \\
\text { years) hypertension } \\
\text { and/or T2D }\end{array}$ & RDBPC parallel groups & $\begin{array}{c}1218 \mathrm{mg} \mathrm{CF}(219 \mathrm{mg} \\
\text { epicatechin). A duration of } \\
24 \mathrm{~h} / 30 \text { days }\end{array}$ & $\begin{array}{l}\text { MMSE; TMT-A and B; TCD of MCA to } \\
\text { assess neurovascular coupling } \\
\text { (baseline and PD) }\end{array}$ & No effects in the primary analysis. \\
\hline Neshatdoust et al. (2016) [25] & $\begin{array}{l}n=40(22 \text { male }) \\
(62-75 \text { years } \\
\text { mean } 68)\end{array}$ & RDBPC crossover & $\begin{array}{l}494 \mathrm{mg} \mathrm{CF} \\
\text { (89 mg epicatechin). } \\
\text { Twenty-eight days }\end{array}$ & $\begin{array}{l}\text { Go-No-Go; Stroop; plus-minus; TMT; letter } \\
\text { memory; free and delayed WR; word and } \\
\text { face recognition; serial sevens; spatial } \\
\text { delayed recall; virtual 3D radial arm maze; } \\
\text { word stem completion; DSST; RVIP } \\
\text { (baseline and PD) }\end{array}$ & $\begin{array}{l}\text { Significant increase in global cognition } \\
\text { and BDNF. }\end{array}$ \\
\hline Desideri et al. (2012) [26] & $\begin{array}{c}n=90 \\
\text { (65-82 years) MCI }\end{array}$ & RDBPC parallel groups & $\begin{array}{l}520 \mathrm{mg} \mathrm{CF} ; 993 \mathrm{mg} \mathrm{CF} \\
\text { (95/185 mg epicatechin). } \\
\text { Eight weeks }\end{array}$ & $\begin{array}{l}\text { MMSE; TMT-A and B; VF } \\
\text { (baseline and PD) }\end{array}$ & $\begin{array}{c}\text { Increased speed of TMT-A and TMT-B. A } \\
\text { total of } 185 \mathrm{mg} \text { improved VF. Reduced IR, } \\
\text { BP and LP, with IR explaining 40\% of } \\
\text { composite } z \text { score variability }\end{array}$ \\
\hline Mastroiacovo et al. (2015) [26] & $n=90$ ( $\sim 69$ years $)$ & RDBPC parallel groups & $\begin{array}{l}520 \mathrm{mg} \mathrm{CF} ; 993 \mathrm{mg} \mathrm{CF} \\
\text { (95/185 mg epicatechin). } \\
\text { Eight weeks }\end{array}$ & $\begin{array}{l}\text { MMSE; TMT-A; TMT-B; VF } \\
\quad \text { (baseline and PD) }\end{array}$ & $\begin{array}{l}\text { Increased speed of TMT-A and TMT-B. A } \\
\text { total of } 185 \mathrm{mg} \text { improved VF. Reduced IR, } \\
\text { BP and LP, with IR explaining } \sim 17 \% \text { of } \\
\text { composite } z \text { score variability. }\end{array}$ \\
\hline Marsh et al. (2017) [28] & $\begin{array}{c}n=12 \\
\text { (post-menopausal } \\
\text { women) (77 years) }\end{array}$ & RSBPC crossover & $\begin{array}{c}200 \mathrm{mg} \mathrm{CF} ; 395 \mathrm{mg} \mathrm{CF} \\
\text { (25 mg/49 mg epicatechin). } \\
\text { Acute }\end{array}$ & $\begin{array}{l}\text { Detection task; } n \text {-back ( } 1 \text { and } 2 \text { back); list } \\
\text { learning and recall; continuous } \\
\text { paired-association learning (separate day } \\
\text { baseline and } 60 \text { min PD). FMD; MAP; HR; } \\
\text { TCD of MCA (baseline and } 60 \text { min PD). }\end{array}$ & $\begin{array}{l}\text { Milk and dark chocolate increased FMD, } \\
\text { decreased CBV at rest and during tasks } \\
\text { with no effects on cognition or MAP. }\end{array}$ \\
\hline \multicolumn{6}{|c|}{ 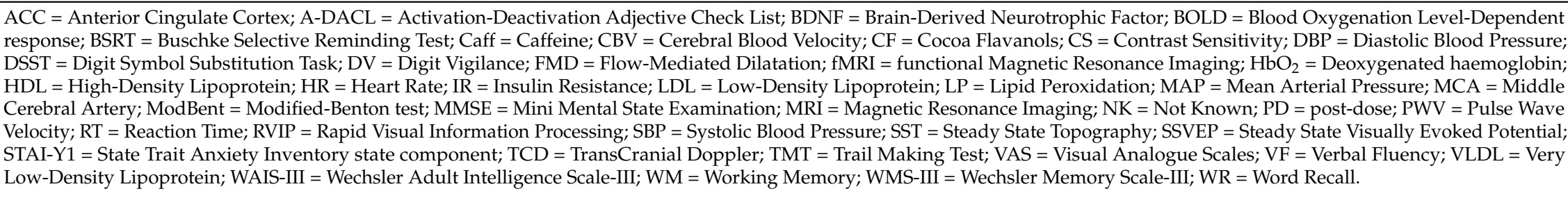 } \\
\hline
\end{tabular}




\section{Potential Mechanisms and Bioavailability}

\subsection{Potential Mechanisms}

The exact mechanisms responsible for the effects of flavanols on brain health are yet to be determined but previous attributions to antioxidant properties have begun to be replaced by functions which impact synaptic plasticity via a cascade of cell signalling mechanisms, such as the modulation of receptor function, gene expression and protein synthesis, improved neuronal survival and increased spine density [29-31]. For instance, the treatment of mouse cortical cells with (-)-epicatechin in the range $30 \mathrm{nmol} / \mathrm{L}-30 \mu \mathrm{mol} / \mathrm{L}$ produced a bell-shaped dose-response on phosphorylation of cyclic adenosine monophosphate (cAMP) response element binding protein (CREB), with a maximum stimulation observed with doses between 100-300 nmol/L. This neuronal response was PI3-kinase and extracellular signal-regulated kinase (ERK) 1/2-dependent, and the phosphorylation of ERK $1 / 2$ and Akt following (-)-epicatechin was shown to follow the same dose-response. Equivalent phosphorylation of ERK was also shown following the $(-)$-epicatechin metabolite, 3'-O-methyl-epicatechin, with no effects of epicatechin glucuronide. Eighteen hours after treatment with $100 \mathrm{nmol} / \mathrm{L}$ epicatechin, cAMP responsive element (CRE) mediated gene expression was shown to be up-regulated in a partially ERK-dependent manner, and the levels of GluR2 protein were increased [32]. Neuroprotective effects of (-)-epicatechin have also been demonstrated through decreased amyloid $\beta-(A \beta)$ induced apoptosis [33], which is related, at least in part, to activation of c-Jun N-terminal protein kinase (JNK) and p38 mitogen-activated protein kinase (MAPK) [34-36].

\subsection{Caveats for Result Interpretation}

Difficulties in elucidating specific mechanisms of action for flavanols are due in part to the variety of compounds present when administered as food. For example, cocoa contains the methylxanthines caffeine and theobromine, along with fat, protein, carbohydrates and a range of minerals, all of which are usually matched in the control intervention but the total flavanol content includes monomers and procyanidins, which are not matched in the control, therefore presenting difficulties in ascribing effects solely to epicatechin. In addition, robust effects on biomarkers in vitro are often not replicated when measured in vivo. One explanation for this is that absorption is limited in vivo and extensive metabolism takes place in the small and large intestine, the liver and in cells. Therefore, due to extensive conjugation and metabolism, the substance administered may differ from that detected in systemic circulation [37,38]. Unlike dimer procyanidins, larger oligomeric flavanols present in cocoa were not detected in relevant levels in human plasma [39]. Previously, unmetabolised (-)-epicatechin has been detected in plasma at $2 \mathrm{~h}$ post-consumption of high flavanol cocoa drink (containing $917 \mathrm{mg}(-)$-epicatechin)) [40]. However, recent studies have failed to detect unmetabolised (-)-epicatechin compounds that were previously identified, suggesting inadequacies in the previous methodologies [41-43]. The identification and quantification of (-)-epicatechin conjugates was incomplete due to a lack of purified standards but new methods emerged indicating inadequacies in earlier methodologies. The rapid metabolism of epicatechin in the small intestine results in glucuronides, sulphates and/or methyl conjugates. For instance, following the consumption of $100 \mathrm{~g}$ of dark chocolate containing $79 \mathrm{mg}$ of (-)-epicatechin, Actis-Goretta et al. [42] identified the following epicatechin metabolites as most relevant: epicatechin- 3 - $-\beta$-D-glucuronide (32\%), epicatechin-3'-sulphate (24\%), and epicatechin-3'-O-methyl-epicatechin sulphates substituted in the $4^{\prime}, 5$, and 7 positions. Despite the variable results, the evidence is emerging with regards the major metabolites and this is expected to continue as techniques and standards are developed. However, the studies described all suffer from extremely low sample sizes and given the large individual differences present it is essential that large-scale studies are conducted to explore the factors impacting on this. In particular, studies often differ with regards restrictions on diet in terms of polyphenol intake, ranging from no restrictions [40] to 12-h [44] and 48-h [42] restricted ('beige') diets. Differences also occur with regards length of fast from $2 \mathrm{~h}$ [44] to $12 \mathrm{~h}[40,42]$. Given the importance of the mucosal 
integrity of the small intestine to absorption and the impact that small intestine microbiota has on this, it is important to explore the impact of dietary restrictions on bioavailability results. As the small intestine microbiota can fluctuate over days and even within a day [45], and as cocoa flavanols have shown prebiotic properties (albeit in faecal samples) [46], the possibility exists that restriction of polyphenol intake prior to bioavailability studies, negatively impacts on microbiota and this, in turn, reduces absorption from the small intestine. Therefore, those people who consume higher levels of polyphenols habitually may show increased absorption in intervention studies and, therefore, greater benefits over their counterparts with a lower level of intake. This also suggests that bioefficacy may be reduced in acute studies where a 'beige' diet is adhered to and this is something that warrants further investigation.

\subsection{Blood-Brain Barrier}

A further issue when considering the impact of epicatechin on brain health is its ability to reach the brain. Epicatechin has been shown to cross the blood-brain barrier (BBB) in vitro and also to be conjugated with glucuronic acid in these endothelial cells [47]. Data from animal studies have also shown epicatechin and its metabolites in brain tissue at pharmacologically relevant levels following oral administration $[48,49]$ and despite data showing lower brain uptake of sulphated and glucuronidated derivatives in vitro [50], animal studies have shown that glucuronides can enter the brain [51,52]. However, the present knowledge on the ability of epicatechin and its metabolites to enter the brain is limited and in the absence of evidence for the biological activity of the metabolites, it is currently not possible to definitively conclude on the potential for epicatechin to exert direct effects on the brain.

\section{Peripheral and Cerebral Blood Flow Intervention Studies}

As the potential for the direct effects of epicatechin on the brain has not been conclusively determined, indirect mechanisms have been explored. One such mechanism is improved blood flow. Several observational studies have linked habitual cocoa intake to lowered risk for a number of blood flow-related conditions such as high blood pressure, coronary heart disease, acute myocardial infarction, heart failure, carotid atherosclerotic plaques and strokes [53-60]. These data from epidemiological studies are supported by a number of intervention studies that have explored acute and chronic effects of cocoa on blood pressure [61-68] and platelet function [69-73]. Several studies have indicated a specific effect of cocoa on endothelial function as demonstrated by the increased flow-mediated dilation (FMD) whether studied chronically $[62,64,68,74,75]$, acutely [65,75-79], or acutely superimposed upon a chronic increase [80,81]. Further support for the importance of endothelial function in this relationship comes from studies showing an absence of the modulation of endothelial-independent brachial artery diameter [64,76,80,81]. Mills et al. also demonstrated an improvement in FMD after the oral ingestion of epicatechin (200 mg) [82]. This effect on FMD was not replicated in older pre-hypertensive adults (40-80 years) when measured chronically or acute-on-chronically following 4-week supplementation with epicatechin (100 mg/day) [83]. Given the available data, it seems unlikely that the effects of epicatechin on FMD are only observed acutely but a dose of $100 \mathrm{mg}$ /day was potentially not sufficient to see these effects in this population. Interestingly, the latter study employed epicatechin extracted from acacia heartwood with aqueous alcohol, possibly indicating an impact of the source and extraction method upon the quality of the epicatechin produced. This is potentially supported by data showing FMD increases in young and elderly participants alike both acutely and following 2-week epicatechin supplementation when administered in the form of cocoa [84].

In the first study to extend the findings of improved peripheral vascular function following cocoa consumption to cerebral blood flow (CBF), arterial spin labelling (ASL) magnetic resonance imaging (MRI) revealed significant increases in grey matter CBF $2 \mathrm{~h}$ post-consumption of $516 \mathrm{mg} \mathrm{CF}$ (93 mg epicatechin) as compared to control in healthy young adults [8]. This is supported by data from a recent study using the same technique showing regional increases particularly in the anterior 
cingulate cortex and the central opercular cortex of the parietal lobe in older adults (55-65 years) at rest [85]. The acute modulation of cerebral haemodynamics was also demonstrated by an increase in deoxygenated haemoglobin in younger adults measured using Near Infrared Spectroscopy both at rest and during the performance of a Stroop task [12]. Conversely, a reduction in CBF velocity measured with Transcranial Doppler (TCD) was reported following milk and dark chocolate, as compared to white chocolate, in post-menopausal women. As this reduction was observed during cognitive tasks with no effects on performance, the authors interpret this as indicating increased cerebrovascular efficiency [28]. Other studies employing TCD have failed to find effects on CBF velocity whether measured acutely (9) or following repeat administration $[15,24,86]$ in samples ranging from 18-to 83-year-olds and employing a range of doses of epicatechin from 25-219 mg. The most salient explanation for these findings is the lack of sensitivity of TCD to detect small changes in cerebral blood velocity due to the variability in signal detection. Conversely, the blood oxygenation level dependent (BOLD) fMRI signal intensity was shown to be significantly increased following 5 days' consumption of epicatechin-rich cocoa as compared to control. Given the previously demonstrated increase in grey matter CBF, it is not clear whether this increase in the BOLD signal indicates an increase in neuronal activity or merely reflects modulation of vascular function. However, as this modulation of activation was apparent in brain areas relevant to the task, it is perhaps surprising that no significant effects on cognitive performance were observed, a finding which indicates that this modulation is not always sufficient to produce measurable behavioural effects in healthy young adults. In the only study to date to demonstrate the modulation of cerebral perfusion in conjunction with cognitive change following $\mathrm{CF}$, increases in cerebral blood volume (CBV) in the right hippocampal circuit were positively correlated with performance on a Modified Benton task in older adults [22].

See Table 2 for an overview of randomised controlled trials assessing the impact of cocoa on brain function. 
Table 2. Randomised controlled trials assessing the effects of cocoa on brain function.

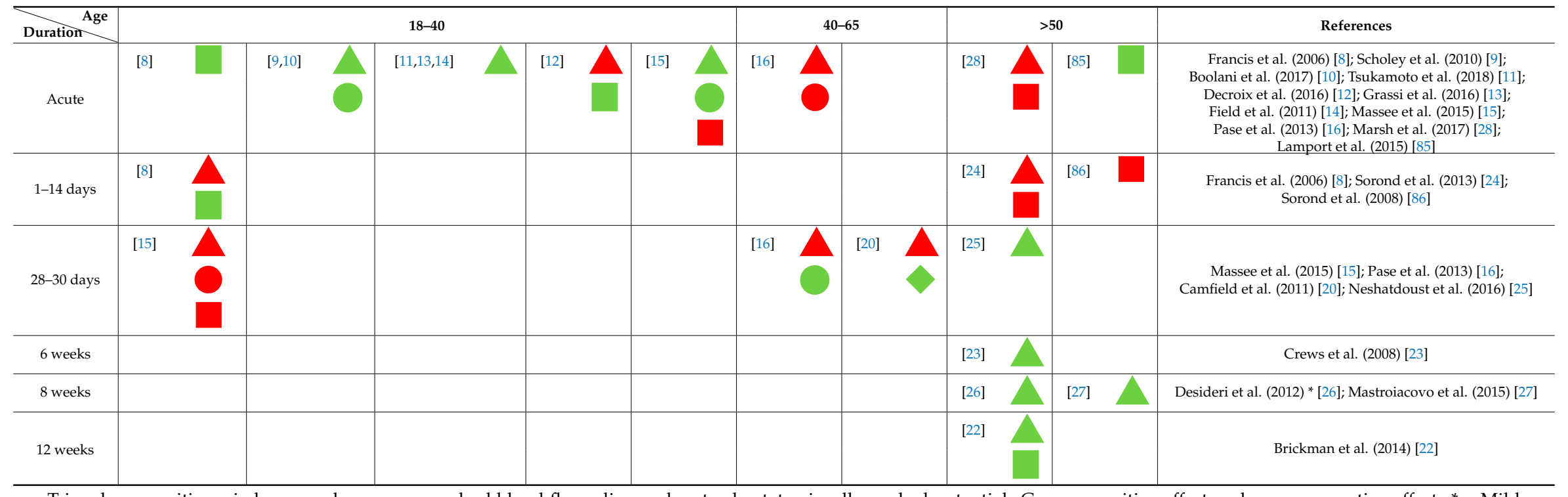

Triangle $=$ cognition; circle $=$ mood; square $=$ cerebral blood flow; diamond $=$ steady-state visually evoked potential. Green $=$ positive effect; red $=$ no or negative effect. $*=$ Mild cognitive impairment. 


\section{Summary of Evidence for Cognitive Effects and Their Relationship to Blood Flow}

Of the eight studies that have assessed the cognitive effects of cocoa in young adults, one showed positive effects that can be confidently attributed to flavan-3-ols [9]; four showed significant improvements but did not explicitly match for other active compounds such as methylxanthines and/or macronutrients $[10,11,13,14]$; others have shown no effects $[8,12]$ or produced only a single effect [15]. Notably of the three studies to demonstrate robust effects, two employed cognitively demanding tasks $[9,10]$ and the other showed effects following sleep deprivation [13]. This indicates that the likelihood of detecting improvements in young adults may be increased in states whereby ceiling effects are prevented. This may also relate to the proposed mechanism of action for such effects as cerebral blood flow is more likely to be compromised in times of increased cognitive demand and when sleep deprived. Neurovascular coupling ensures that increases in demand for the metabolic substrates glucose and oxygen, as a consequence of neuronal activity, are met by increased cerebral blood flow. However, tasks or paradigms that are particularly difficult or fatiguing may increase demands to a level whereby it is possible that the increased supply of substrates may be beneficial. Similarly, CBF has been shown to be reduced both in sleepwalkers when compared to controls [87] and following 48-h acute deprivation [88], particularly in the prefrontal cortex. Therefore, as an impairment to neurovascular coupling is rare in healthy young adults, increases in CBF may only result in cognitive improvements when this is compromised either through increased demand or reductions in supply, for example following sleep deprivation.

A lack of cognitive effects has been shown in middle-age $[16,20]$, which may reflect the complexities inherent in assessing cognition in those potentially suffering currently undiagnosed comorbidities. However, studies in older adults have shown positive effects on cognition in four out of seven studies. Improvements were shown to trail making and verbal fluency [26,27] and to object recognition [22], as well as global cognition [25]. Importantly, the only one of these studies to measure cerebral blood flow showed a significant correlation between change in cognition and change in CBV [22]. Of the three studies in older adults that showed null findings on cognition, the first is likely due to mismatches in sugar and sweetener levels between the placebo and active treatments [23]. The second [24] potentially relates to the 4-week intervention employed and the diagnosis of participants as hypertensive or type II diabetic. Although significant improvements have been reported in older healthy participants following 4 weeks' CF consumption [25], it is possible that a longer supplementation is required in those diagnosed with clinical impairment to vascular function. No significant effects were observed in healthy elderly following acute supplementation [28], which potentially supports the assertion that an increased length of administration may be required in accordance with vascular function senescence. However, as cerebral vascular function decreases with age, as evidenced by reductions in cerebral blood velocity [89], activation, and coupling between oxygenated and deoxygenated haemoglobin [90], it is possible that effects of epicatechin are more likely to be detected in older populations. The reasons for this are two-fold, as vascular risk factors are associated with cognitive impairment [91], this decline with ageing helps to eradicate the confound of ceiling effects suggested in healthy young adults; and declines in cerebrovascular function with age provide a mechanism for impacting cognition through improvements to vascular health. This latter suggestion is supported by data showing that $\mathrm{CF}$ induced improvement in endothelial function was greatest in older adults relative to younger adults [92].

Endothelial function decreases with age as the capacity to produce nitric oxide (NO) diminishes. NO formed by endothelial NO synthase (eNOS) has a number of impacts on vascular health such as increased vasodilation and blood flow and decreased vascular resistance, hypotension, platelet aggregation and adhesion [93]. Increases in plasma nitric oxide metabolites have been observed within one hour of consumption of flavanol-rich food [40,77] and following (-)-epicatechin in isolation [94] and a wealth of evidence demonstrates the importance of this to effects of CF on peripheral blood flow effects. Acutely, plasma nitric oxide species have been positively correlated with FMD [76] and a reversal of this was observed following the inhibition of nitric oxide synthase by intravenous infusion 
of L-NG-monomethyl-arginine nitrite (LNMMA) [77]. Chronically, increases in nitrite (an oxidative metabolite of nitric oxide) [80] have been observed, as well as circulating angiogenic cells [68], which are linked to endothelial nitric oxide synthase [95]. The effects of NO are particularly important with regards cerebrovascular function due to the tight control of this system and the reliance on a continuous flow of blood to supply neural substrates. Therefore, in addition to effects on basal CBF of endothelial $\mathrm{NO}$, neuronal NO plays a crucial role in regulating neurovascular coupling to ensure neuronal activity is met by sufficient increases in CBF [96], as well as impacting neuroplasticity [97]. The role of NO in CBF effects of ageing is highlighted by the observation that L-arginine (the immediate precursor to NO) increased the cerebral blood flow velocity to a lesser extent in older adults ( 70 years) than younger ones ( 29 years) [98], and that a decrease in CBF is demonstrated in older but not young adults following infusion of L-NMMA [99], suggesting that the NO pathway is less involved in the regulation of basal blood flow in young subjects, or that mechanisms exist to compensate for its disruption. This latter finding supports the suggestion that cognitive improvements via increased CBF may be less likely to be observed in healthy young adults. Therefore, in order to further understand the relationship of CBF to the cognitive effects of epicatechin and to further elucidate the role of NO in any effects, it is essential that future studies concurrently measure CBF and cognition. It is particularly important that $\mathrm{CBF}$ is measured at rest and during task performance in order to disentangle any global effects on CBF from those relating to neuronal demand. It is also worth noting that whilst the focus of this review is the role of $\mathrm{CBF}$, the inclusion of other brain MRI measures such as neuroinflammation, white matter disease, and amyloid deposition/clearance would help elucidate the impact of epicatechin on cognition.

\section{Conclusions and Future Directions}

At present, it is difficult to make definitive conclusions regarding the impact of the consumption of epicatechin on cognition due to a paucity of data. However, evidence is emerging which suggests a positive modulation of tasks that involve memory, executive function and processing speed in older adults following cocoa flavanol (CF) interventions where the major active component is purported to be (-)-epicatechin [22,25-27]. Due to a lack of consistency in tasks employed across studies, direct replication of these effects cannot be confirmed or disputed in young adults, but similarities exist whereby improvement has been shown to tasks which involve varying contributions of information processing, working memory, and psychomotor speed following CF $[9,10,13,15]$. In order to further explore the role of age in any effects, it is necessary to design studies that include older and young adults, particularly in light of age-associated reductions in eNOS expression [100]. In addition, as cognitive effects have tended to only be measured acutely in young adults whereas effects in older adults have typically involved $\geq 4$ weeks' intervention, the impact of the length of intervention is also something that requires further clarification in relation to age. This is particularly apparent when considering that improvements to calm and content mood ratings were shown following 4 weeks' intervention in middle-aged adults, but not acutely [16]. Moreover, the length of the intervention may represent an important difference between observational and intervention studies given the longest supplementation period to date is 12 weeks. It is therefore important to conduct longer studies which also include a follow-up period to assess the longevity of effects. This would add to data from studies of phenolic-rich grape juice showing carryover effects indicative of enduring benefits whether consumed for 12 weeks [101] or acutely [102]. Furthermore, differences in response to epicatechin as a function of sex have generally not been explored, as is often the case in nutrition intervention studies, and this is something that should be addressed, particularly in light of cognitive effects shown in females only following sleep deprivation [13].

In terms of dose, studies to date have employed doses of CF ranging from 172-994 mg with reported epicatechin levels ranging from $25-447 \mathrm{mg}$. With the exception of studies in middle-aged participants, studies including those selected on the basis of a clinical diagnosis, and one study that may have been underpowered, positive cognitive effects were shown in studies employing 
doses $\geq 494 \mathrm{mg} \mathrm{CF} /$ day. These studies provided supplements that contained more than $50 \mathrm{mg}$ epicatechin/day were reported. However, the level of epicatechin is not always reported and interventions differ in other aspects of composition making it difficult to conclusively attribute effects to epicatechin level. This highlights the need for further studies which delineate the role of epicatechin, either through the design of studies that allow effects of epicatechin-rich foods to be attributed to epicatechin or through the supplementation of epicatechin, and its metabolites where possible, in isolation. A further method to elucidate the role of epicatechin, and particularly metabolites, is to include the blood measures of these compounds and examine the relationship between these and cognitive outcome measures.

Mechanistically, although NO has been highlighted as an important pathway for blood flow effects of $\mathrm{CF}$ and improvement to endothelial function has been suggested as a mediator in cognitive effects of $\mathrm{CF}$, this relationship is extremely complex and requires further exploration along with other potential mechanisms of action. In older adults, increases in CBV have been correlated with cognitive improvements but this finding requires replication and other factors should be considered alongside blood flow effects. In the case of younger adults, although blood flow to the brain has been shown to increase following $\mathrm{CF}$, this mechanism has not proved sufficient to produce cognitive improvements. This does not rule out this mechanism of action in certain circumstances but does provide evidence that increases in CBF do not necessarily lead to cognitive benefits. In order to further clarify the role of NO in modulations to $\mathrm{CBF}$ and cognition, methodologies similar to those in FMD studies should be employed whereby plasma nitric oxide metabolites were measured $[40,77,94]$ and the impact of inhibition of nitric oxide synthase on blood flow effects was assessed [77,103]. Interestingly, $100 \mathrm{mg} /$ day of (-)-epicatechin failed to increase FMD or NO in pre-hypertensives despite significant decreases in the related parameters of fasting insulin and insulin resistance [83]. Given its association with endothelial function and blood flow, the role of insulin and insulin resistance requires further exploration in relation to epicatechin, particularly as it has been shown to predict the overall cognitive performance changes following CF supplementation [26,27]. Finally, future studies of epicatechin should also consider the effects on mood and the potential for this to modulate cognitive effects. Pase et al. [16] demonstrated a significant improvement to content and calm ratings following 30 days' $\mathrm{CF}$ supplementation, which they suggest may relate to effects on $\mathrm{GABA}_{\mathrm{A}}$ receptors. However, mental stress also impairs endothelial function [104], so it is possible that demand is necessary to impair this in order to see effects in young subjects; this should be explored by employing tasks that allow modulation of demand in order to investigate the impact of this across ages, whilst concurrently measuring mood.

Although promising evidence is beginning to emerge with regards the impact of (-)-epicatechin on cognition, it is not currently possible to attribute effects solely to epicatechin without consideration of synergies. In order to overcome this issue, future studies require the use of epicatechin in isolation. In addition, to avoid the issue of null findings on cognition often observed in nutritional intervention studies, it is essential that appropriate, hypothesis-driven tasks, are employed. Similarly, although studies including 28 days or more supplementation in $>50$-year-olds all showed positive effects on cognition, there is a lack of evidence regarding the optimal dose and time-frame for cognitive effects. Therefore, large-scale studies are needed that take these factors into account along with age, sex and habitual diet, whilst also assessing bioavailability and correlating this with any cognitive effects.

Author Contributions: All authors contributed to the writing of this review.

Funding: This review was funded by Nestec SA, Vevey, Switzerland.

Acknowledgments: The authors would like to thank Beata Silber for her comments on an earlier draft of this article.

Conflicts of Interest: Jeroen Schmitt and Lucas Actis-Goretta are employees of Nestec SA, which is a subsidiary of Nestlé Ltd, and provides professional assistance, research, and consulting services for food, dietary, dietetic, and pharmaceutical products of interest to Nestlé Ltd. 


\section{References}

1. Commenges, D.; Scotet, V.; Renaud, S.; Jacqmin-Gadda, H.; Barberger-Gateau, P.; Dartigues, J.F. Intake of flavonoids and risk of dementia. Eur. J. Epidemiol. 2000, 16, 357-363. [CrossRef] [PubMed]

2. Letenneur, L.; Proust-Lima, C.; Le Gouge, A.; Dartigues, J.F.; Barberger-Gateau, P. Flavonoid intake and cognitive decline over a 10-year period. Am. J. Epidemiol. 2007, 165, 1364-1371. [CrossRef] [PubMed]

3. Kuriyama, S.; Hozawa, A.; Ohmori, K.; Shimazu, T.; Matsui, T.; Ebihara, S.; Awata, S.; Nagatomi, R.; Arai, H.; Tsuji, I. Green tea consumption and cognitive function: A cross-sectional study from the Tsurugaya Project. Am. J. Clin. Nutr. 2006, 83, 355-361. [CrossRef] [PubMed]

4. Ng, T.P.; Feng, L.; Niti, M.; Kua, E.H.; Yap, K.B. Tea consumption and cognitive impairment and decline in older Chinese adults. Am. J. Clin. Nutr. 2008, 88, 224-231. [CrossRef] [PubMed]

5. Feng, L.; Gwee, X.; Kua, E.H.; Ng, T.P. Cognitive function and tea consumption in community dwelling older Chinese in Singapore. J. Nutr. Health Aging 2010, 14, 433-438. [CrossRef] [PubMed]

6. Nurk, E.; Refsum, H.; Drevon, C.A.; Tell, G.S.; Nygaard, H.A.; Engedal, K.; Smith, A.D. Intake of flavonoid-rich wine, tea, and chocolate by elderly men and women is associated with better cognitive test performance. J. Nutr. 2009, 139, 120-127. [CrossRef] [PubMed]

7. Neafsey, E.J.; Collins, M.A. Moderate alcohol consumption and cognitive risk. Neuropsychiatr. Dis. Treat. 2011, 7, 465-484. [CrossRef] [PubMed]

8. Francis, S.T.; Head, K.; Morris, P.G.; Macdonald, I.A. The effect of flavanol-rich cocoa on the fMRI response to a cognitive task in healthy young people. J. Cardiovasc. Pharmacol. 2006, 47, S215-S220. [CrossRef] [PubMed]

9. Scholey, A.B.; French, S.J.; Morris, P.J.; Kennedy, D.O.; Milne, A.L.; Haskell, C.F. Consumption of cocoa flavanols results in acute improvements in mood and cognitive performance during sustained mental effort. J. Psychopharmacol. 2010, 24, 1505-1514. [CrossRef] [PubMed]

10. Boolani, A.; Lindheimer, J.B.; Loy, B.D.; Crozier, S.; O'Connor, P.J. Acute effects of brewed cocoa consumption on attention, motivation to perform cognitive work and feelings of anxiety, energy and fatigue: A randomized, placebo-controlled crossover experiment. BMC Nutr. 2017, 3, 8. [CrossRef]

11. Tsukamoto, H.; Suga, T.; Ishibashi, A.; Takenaka, S.; Tanaka, D.; Hirano, Y.; Hamaoka, T.; Goto, K.; Ebi, K.; Isaka, T; et al. Flavanol-rich cocoa consumption enhances exercise-induced executive function improvements in humans. Nutrition 2018, 46, 90-96. [CrossRef] [PubMed]

12. Decroix, L.; Tonoli, C.; Soares, D.D.; Tagougui, S.; Heyman, E.; Meeusen, R. Acute cocoa flavanol improves cerebral oxygenation without enhancing executive function at rest or after exercise. Appl. Physiol. Nutr. Metab. 2016, 41, 1225-1232. [CrossRef] [PubMed]

13. Grassi, D.; Socci, V.; Tempesta, D.; Ferri, C.; De Gennaro, L.; Desideri, G.; Michele, F. Flavanol-rich chocolate acutely improves arterial function and working memory performance counteracting the effects of sleep deprivation in healthy individuals. J. Hypertens. 2016, 34, 1298-1308. [CrossRef] [PubMed]

14. Field, D.T.; Williams, C.M.; Butler, L.T. Consumption of cocoa flavanols results in an acute improvement in visual and cognitive functions. Physiol. Behav. 2011, 103, 255-260. [CrossRef] [PubMed]

15. Massee, L.A.; Ried, K.; Pase, M.; Travica, N.; Yoganathan, J.; Scholey, A.; Scholey, A.; Macpherson, H.; Kennedy, G.; Sali, A.; et al. The acute and sub-chronic effects of cocoa flavanols on mood, cognitive and cardiovascular health in young healthy adults: A randomized, controlled trial. Front. Pharmacol. 2015, 6, 93. [CrossRef] [PubMed]

16. Pase, M.P.; Scholey, A.B.; Pipingas, A.; Kras, M.; Nolidin, K.; Gibbs, A.; Wesnes, K.; Stough, C. Cocoa polyphenols enhance positive mood states but not cognitive performance: A randomized, placebo-controlled trial. J. Psychopharmacol. 2013, 27, 451-458. [CrossRef] [PubMed]

17. Scholey, A.B.; Tildesley, N.T.J.; Ballard, C.G.; Wesnes, K.A.; Tasker, A.; Perry, E.K.; Kennedy, D.O. An extract of Salvia (sage) with anticholinesterase properties improves memory and attention in healthy older volunteers. Psychopharmacology 2008, 198, 127-139. [CrossRef] [PubMed]

18. Haskell, C.F.; Scholey, A.B.; Jackson, P.A.; Elliott, J.M.; Defeyter, M.A.; Greer, J.; Robertson, B.C.; Buchanan, T.; Tiplady, B.; Kennedy, D.O. Cognitive and mood effects in healthy children during 12 weeks' supplementation with multi-vitamin/minerals. Br. J. Nutr. 2008, 100, 1086-1096. [CrossRef] [PubMed]

19. Bond, A.; Lader, M. Use of analog scales in rating subjective feelings. Br. J. Med. Psychol. 1974, 47, $211-218$. [CrossRef] 
20. Camfield, D.A.; Scholey, A.; Pipingas, A.; Silberstein, R.; Kras, M.; Nolidin, K.; Wesnes, K.; Pase, M.; Stougha, C. Steady state visually evoked potential (SSVEP) topography changes associated with cocoa flavanol consumption. Physiol. Behav. 2012, 105, 948-957. [CrossRef] [PubMed]

21. Silberstein, R.B.; Nunez, P.L.; Pipingas, A.; Harris, P.; Danieli, F. Steady state visually evoked potential (SSVEP) topography in a graded working memory task. Int. J. Psychophysiol. 2001, 42, 219-232. [CrossRef]

22. Brickman, A.M.; Khan, U.A.; Provenzano, F.A.; Yeung, L.K.; Suzuki, W.; Schroeter, H.; Wall, M.; Sloan, R.P.; Small, S.A. Enhancing dentate gyrus function with dietary flavanols improves cognition in older adults. Nat. Neurosci. 2014, 17, 1798-1803. [CrossRef] [PubMed]

23. Crews, W.D., Jr.; Harrison, D.W.; Wright, J.W. A double-blind, placebo-controlled, randomized trial of the effects of dark chocolate and cocoa on variables associated with neuropsychological functioning and cardiovascular health: Clinical findings from a sample of healthy, cognitively intact older adults. Am. J. Clin. Nutr. 2008, 87, 872-880. [PubMed]

24. Sorond, F.A.; Hurwitz, S.; Salat, D.H.; Greve, D.N.; Fisher, N.D. Neurovascular coupling, cerebral white matter integrity, and response to cocoa in older people. Neurology 2013, 81, 904-909. [CrossRef] [PubMed]

25. Neshatdoust, S.; Saunders, C.; Castle, S.M.; Vauzour, D.; Williams, C.; Butler, L.; Lovegrove, J.A.; Spencer, J.P.E. High-flavonoid intake induces cognitive improvements linked to changes in serum brain-derived neurotrophic factor: Two randomised, controlled trials. Nutr. Healthy Aging 2016, 4, 81-93. [CrossRef] [PubMed]

26. Desideri, G.; Kwik-Uribe, C.; Grassi, D.; Necozione, S.; Ghiadoni, L.; Mastroiacovo, D.; Raffaele, A.; Ferri, L.; Bocale, R.; Lechiara, M.C.; et al. Benefits in cognitive function, blood pressure, and insulin resistance through cocoa flavanol consumption in elderly subjects with mild cognitive impairment: The Cocoa, Cognition, and Aging (CoCoA) study. Hypertension 2012, 60, 794-801. [CrossRef] [PubMed]

27. Mastroiacovo, D.; Kwik-Uribe, C.; Grassi, D.; Necozione, S.; Raffaele, A.; Pistacchio, L.; Righetti, R.; Bocale, R.; Lechiara, M.C.; Marini, C.; et al. Cocoa flavanol consumption improves cognitive function, blood pressure control, and metabolic profile in elderly subjects: The Cocoa, Cognition, and Aging (CoCoA) Study-A randomized controlled trial. Am. J. Clin. Nutr. 2015, 101, 538-548. [CrossRef] [PubMed]

28. Marsh, C.E.; Carter, H.H.; Guelfi, K.J.; Smith, K.J.; Pike, K.E.; Naylor, L.H.; Green, D.J. Brachial and Cerebrovascular Functions Are Enhanced in Postmenopausal Women after Ingestion of Chocolate with a High Concentration of Cocoa. J. Nutr. 2017, 147, 1686-1692. [CrossRef] [PubMed]

29. Spencer, J. The interactions of flavonoids within neuronal signalling pathways. Genes Nutr. 2007, 2, $257-273$. [CrossRef] [PubMed]

30. Spencer, J.P. Flavonoids and brain health: Multiple effects underpinned by common mechanisms. Genes Nutr. 2009, 4, 243-250. [CrossRef] [PubMed]

31. Williams, R.J.; Spencer, J.P. Flavonoids, cognition, and dementia: Actions, mechanisms, and potential therapeutic utility for Alzheimer disease. Free Radic. Biol. Med. 2012, 52, 35-45. [CrossRef] [PubMed]

32. Schroeter, H.; Bahia, P.; Spencer, J.P.E.; Sheppard, O.; Rattray, M.; Cadenas, E.; Rice-Evans, C.; Williams, R.J. (-) Epicatechin stimulates ERK-dependent cyclic AMP response element activity and up-regulates GluR2 in cortical neurons. J. Neurochem. 2007, 101, 1596-1606. [CrossRef] [PubMed]

33. Heo, H.J.; Lee, C.Y. Epicatechin and catechin in cocoa inhibit amyloid 6 protein induced apoptosis. J. Agric. Food. Chem. 2005, 53, 1445-1448. [CrossRef] [PubMed]

34. Cho, E.S.; Lee, K.W.; Lee, H.J. Cocoa procyanidins protect PC12 cells from hydrogen-peroxide-induced apoptosis by inhibiting activation of p38 MAPK and JNK. Mutat. Res. 2008, 640, 123-130. [CrossRef] [PubMed]

35. Cho, E.S.; Jang, Y.J.; Kang, N.J.; Hwang, M.K.; Kim, Y.T.; Lee, K.W.; Lee, H.J. Cocoa procyanidins attenuate 4-hydroxynonenal-induced apoptosis of PC12 cells by directly inhibiting mitogen-activated protein kinase kinase 4 activity. Free Radic. Biol. Med. 2009, 46, 1319-1327. [CrossRef] [PubMed]

36. Ramiro-Puig, E.; Casadesús, G.; Lee, H.-G.; Zhu, X.; McShea, A.; Perry, G.; Pérez-Cano, F.J.; Smith, M.A.; Castell, M. Neuroprotective effect of cocoa flavonids on in vitro oxidative stress. Eur. J. Nutr. 2009, 48, 54-61. [CrossRef] [PubMed]

37. Manach, C.; Donovan, J.L. Pharmacokinetics and metabolism of dietary flavonoids in humans. Free Radic. Res. 2004, 38, 771-785. [CrossRef] [PubMed] 
38. Rein, M.J.; Renouf, M.; Cruz-Hernandez, C.; Actis-Goretta, L.; Thakkar, S.K.; Pinto, M.D.S. Bioavailability of bioactive food compounds: A challenging journey to bioefficacy. Br. J. Clin. Pharmacol. 2013, 75, 588-602. [CrossRef] [PubMed]

39. Ottaviani, J.I.; Kwik-Uribe, C.; Keen, C.L.; Schroeter, H. Intake of dietary procyanidins does not contribute to the pool of circulating flavanols in humans. Am. J. Clin. Nutr. 2012, 95, 851-858. [CrossRef] [PubMed]

40. Schroeter, H.; Heiss, C.; Balzer, J.; Kleinbongard, P.; Keen, C.L.; Hollenberg, N.K.; Sies, H.; Kwik-Uribe, C.; Schmitz, H.H.; Kelm, M. (-)-Epicatechin mediates beneficial effects of flavanol-rich cocoa on vascular function in humans. Proc. Natl. Acad. Sci. USA 2006, 103, 1024-1029. [CrossRef] [PubMed]

41. Actis-Goretta, L.; Leveques, A.; Rein, M.; Teml, A.; Schafer, C.; Hofmann, U.; Li, H.; Schwab, M.; Eichelbaum, M.; Williamson, G. Intestinal absorption, metabolism, and excretion of (-)-epicatechin in healthy humans assessed by using an intestinal perfusion technique. Am. J. Clin. Nutr. 2013, 98, 924-933. [CrossRef] [PubMed]

42. Actis-Goretta, L.; Leveques, A.; Giuffrida, F.; Romanov-Michailidis, F.; Viton, F.; Barron, D.; Duenas-Paton, M.; Gonzalez-Manzano, S.; Santos-Buelga, C.; Williamsonac, G. Elucidation of (-)-epicatechin metabolites after ingestion of chocolate by healthy humans. Free Radic. Biol. Med. 2012, 53, 787-795. [CrossRef] [PubMed]

43. Ottaviani, J.I.; Momma, T.Y.; Kuhnle, G.K.; Keen, C.L.; Schroeter, H. Structurally related (-)-epicatechin metabolites in humans: Assessment using de novo chemically synthesized authentic standards. Free Radic. Biol. Med. 2012, 15, 1403-1412. [CrossRef] [PubMed]

44. Barnett, C.F.; Moreno-Ulloa, A.; Shiva, S.; Ramirez-Sanchez, I.; Taub, P.R.; Su, Y.; Ceballos, G.; Dugar, S.; Schreinerf, G.; Villarreal, F. Pharmacokinetic, partial pharmacodynamic and initial safety analysis of (-)-epicatechin in healthy volunteers. Food Funct. 2015, 6, 824-833. [CrossRef] [PubMed]

45. El Aidy, S.; van den Bogert, B.; Kleerebezem, M. The small intestine microbiota, nutritional modulation and relevance for health. Curr. Opin. Biotechnol. 2015, 32, 14-20. [CrossRef] [PubMed]

46. Tzounis, X.; Rodriguez-Mateos, A.; Vulevic, J.; Gibson, G.R.; Kwik-Uribe, C.; Spencer, J.P.E. Prebiotic evaluation of cocoa-derived flavanols in healthy humans by using a randomized, controlled, double-blind, crossover intervention study. Am. J. Clin. Nutr. 2011, 93, 62-72. [CrossRef] [PubMed]

47. Faria, A.; Pestana, D.; Teixeira, D.; Couraud, P.-O.; Romero, I.; Weksler, B.; de Freitas, V.; Mateus, N.; Calhau, C. Insights into the putative catechin and epicatechin transport across blood-brain barrier. Food Funct. 2011, 2, 39-44. [CrossRef] [PubMed]

48. Wang, J.; Ferruzzi, M.G.; Ho, L.; Blount, J.; Janle, E.M.; Gong, B.; Pan, Y.; Gowda, G.N.; Raftery, D.; Arrieta-Cruz, I.; et al. Brain-targeted proanthocyanidin metabolites for alzheimer's disease treatment. J. Neurosci. 2012, 32, 5144-5150. [CrossRef] [PubMed]

49. Van Praag, H.; Lucero, M.J.; Yeo, G.W.; Stecker, K.; Heivand, N.; Zhao, C.; Yip, E.; Afanador, M.; Schroeter, H.; Hammerstone, J.; et al. Plant-derived flavanol (-) epicatechin enhances angiogenesis and retention of spatial memory in mice. J. Neurosci. 2007, 27, 5869-5878. [CrossRef] [PubMed]

50. Youdim, K.A.; Dobbie, M.S.; Kuhnle, G.; Proteggente, A.R.; Abbott, N.J.; Rice-Evans, C. Interaction between flavonoids and the blood-brain barrier: In vitro studies. J. Neurochem. 2003, 85, 180-192. [CrossRef] [PubMed]

51. Bengtsson, J.; Ederoth, P.; Ley, D.; Hansson, S.; Amer-Wåhlin, I.; Hellström-Westas, L.; Marsal, K.; Nordström, C.H.; Hammarlund-Udenaes, M. The influence of age on the distribution of morphine and morphine-3-glucuronide across the blood-brain barrier in sheep. Br. J. Pharmacol. 2009, 157, 1085-1096. [CrossRef] [PubMed]

52. Aasmundstad, T.A.; Morland, J.; Paulsen, R.E. Distribution of morphine 6-glucuronide and morphine across the blood-brain-barrier in awake, freely moving rats investigated by in-vivo microdialysis sampling. J. Pharmacol. Exp. Ther. 1995, 275, 435-441. [PubMed]

53. Buijsse, B.; Feskens, E.J.M.; Kok, F.J.; Kromhout, D. Cocoa intake, blood pressure, and cardiovascular mortality-The Zutphen Elderly Study. Arch. Intern. Med. 2006, 166, 411-417. [CrossRef] [PubMed]

54. Buijsse, B.; Weikert, C.; Drogan, D.; Bergmann, M.; Boeing, H. Chocolate consumption in relation to blood pressure and risk of cardiovascular disease in German adults. Eur. Heart J. 2010, 31, 1616-1623. [CrossRef] [PubMed]

55. Djousse, L.; Hopkins, P.N.; North, K.E.; Pankow, J.S.; Arnett, D.K.; Ellison, R.C. Chocolate consumption is inversely associated with prevalent coronary heart disease: The National Heart, Lung, and Blood Institute Family Heart Study. Clin. Nutr. 2011, 30, 182-187. [CrossRef] [PubMed] 
56. Janszky, I.; Mukamal, K.J.; Ljung, R.; Ahnve, S.; Ahlbom, A.; Hallqvist, J. Chocolate consumption and mortality following a first acute myocardial infarction: The Stockholm Heart Epidemiology Program. J. Intern. Med. 2009, 266, 248-257. [CrossRef] [PubMed]

57. Mostofsky, E.; Levitan, E.B.; Wolk, A.; Mittleman, M.A. Chocolate intake and incidence of heart failure a population-based prospective study of middle-aged and elderly women. Circ. Heart Fail. 2010, 3, 612-616. [CrossRef] [PubMed]

58. Lewis, J.R.; Prince, R.L.; Zhu, K.; Devine, A.; Thompson, P.L.; Hodgson, J.M. Habitual chocolate intake and vascular disease: A prospective study of clinical outcomes in older women. Arch. Intern. Med. 2010, 170, 1857-1858. [CrossRef] [PubMed]

59. Larsson, S.C.; Virtamo, J.; Wolk, A. Chocolate consumption and risk of stroke in women. J. Am. Coll. Cardiol. 2011, 58, 1828-1829. [CrossRef] [PubMed]

60. Bayard, V.; Chamorro, F.; Motta, J.; Hollenberg, N.K. Does flavanol intake influence mortality from nitric oxide-dependent processes? Ischemic heart disease, stroke, diabetes mellitus, and cancer in Panama. Int. J. Med. Sci. 2007, 4, 53-58. [CrossRef] [PubMed]

61. Fraga, C.G.; Actis-Goretta, L.; Ottaviani, J.I.; Carrasquedo, F.; Lotito, S.B.; Lazarus, S.; Schmitz, H.H.; Keen, C.L. Regular consumption of a flavanol-rich chocolate can improve oxidant stress in young soccer players. Clin. Dev. Immunol. 2005, 12, 11-17. [CrossRef] [PubMed]

62. Grassi, D.; Necozione, S.; Lippi, C.; Croce, G.; Valeri, L.; Pasqualetti, P.; Desideri, G.; Blumberg, J.B.; Ferri, C. Cocoa reduces blood pressure and insulin resistance and improves endothelium-dependent vasodilation in hypertensives. Hypertension 2005, 46, 398-405. [CrossRef] [PubMed]

63. Grassi, D.; Lippi, C.; Necozione, S.; Desideri, G.; Ferri, C. Short-term administration of dark chocolate is followed by a significant increase in insulin sensitivity and a decrease in blood pressure in healthy persons. Am. J. Clin. Nutr. 2005, 81, 611-614. [CrossRef] [PubMed]

64. Grassi, D.; Desideri, G.; Necozione, S.; Lippi, C.; Casale, R.; Properzi, G.; Blumberg, J.B.; Ferri, C. Blood pressure is reduced and insulin sensitivity increased in glucose-intolerant, hypertensive subjects after 15 days of consuming high-polyphenol dark chocolate. J. Nutr. 2008, 138, 1671-1676. [CrossRef] [PubMed]

65. Faridi, Z.; Njike, V.Y.; Dutta, S.; Ali, A.; Katz, D.L. Acute dark chocolate and cocoa ingestion and endothelial function: A randomized controlled crossover trial. Am. J. Clin. Nutr. 2008, 88, 58-63. [CrossRef] [PubMed]

66. Taubert, D.; Berkels, R.; Roesen, R.; Klaus, W. Chocolate and blood pressure in elderly individuals with isolated systolic hypertension. JAMA 2003, 290, 1029-1030. [CrossRef] [PubMed]

67. Taubert, D.; Roesen, R.; Lehmann, C.; Jung, N.; Schoemig, E. Effects of low habitual cocoa intake on blood pressure and bioactive nitric oxide-A randomized controlled trial. JAMA 2007, 298, 49-60. [CrossRef] [PubMed]

68. Heiss, C.; Jahn, S.; Taylor, M.; Real, W.M.; Angeli, F.S.; Wong, M.L.; Amabile, N.; Prasad, M.; Rassaf, T.; Ottaviani, J.I.; et al. Improvement of endothelial function with dietary flavanols is associated with mobilization of circulating angiogenic cells in patients with coronary artery disease. J. Am. Coll. Cardiol. 2010, 56, 218-224. [CrossRef] [PubMed]

69. Murphy, K.J.; Chronopoulos, A.K.; Singh, I.; Francis, M.A.; Moriarty, H.; Pike, M.J.; Turner, A.H.; Mann, N.J.; Sinclair, A.J. Dietary flavanols and procyanidin oligomers from cocoa (Theobroma cacao) inhibit platelet function. Am. J. Clin. Nutr. 2003, 77, 1466-1473. [CrossRef] [PubMed]

70. Hamed, M.S.; Gambert, S.; Bliden, K.P.; Bailon, O.; Singla, A.; Antonino, M.J.; Hamed, F.; Tantry, U.S.; Gurbel, P.A. Dark chocolate effect on platelet activity, C-reactive protein and lipid profile: A pilot study. South. Med. J. 2008, 101, 1203-1208. [CrossRef] [PubMed]

71. Monagas, M.; Khan, N.; Andres-Lacueva, C.; Casas, R.; Urpi-Sarda, M.; Llorach, R.; Lamuela-Raventos, R.M.; Estruch, R. Effect of cocoa powder on the modulation of inflammatory biomarkers in patients at high risk of cardiovascular disease. Am. J. Clin. Nutr. 2009, 90, 1144-1150. [CrossRef] [PubMed]

72. Flammer, A.J.; Hermann, F.; Sudano, I.; Spieker, L.; Hermann, M.; Cooper, K.A.; Serafini, M.; Lüscher, T.F.; Ruschitzka, F.; Noll, G.; et al. Dark chocolate improves coronary vasomotion and reduces platelet reactivity. Circulation 2007, 116, 2376-2382. [CrossRef] [PubMed]

73. Hermann, F.; Spieker, L.E.; Ruschitzka, F.; Sudano, I.; Hermann, M.; Binggeli, C.; Lüscher, T.F.; Riesen, W.; Noll, G.; Corti, R. Dark chocolate improves endothelial and platelet function. Heart 2006, 92, 119-120. [CrossRef] [PubMed] 
74. Engler, M.B.; Engler, M.M.; Chen, C.Y.; Malloy, M.J.; Browne, A.; Chiu, E.Y.; Kwak, H.K.; Milbury, P.; Paul, S.M.; Blumberg, J.; et al. Flavonoid-rich dark chocolate improves endothelial function and increases plasma epicatechin concentrations in healthy adults. J. Am. Coll. Nutr. 2004, 23, 197-204. [CrossRef] [PubMed]

75. Davison, K.; Coates, A.M.; Buckley, J.D.; Howe, P.R.C. Effect of cocoa flavanols and exercise on cardiometabolic risk factors in overweight and obese subjects. Int. J. Obes. 2008, 32, 1289-1296. [CrossRef] [PubMed]

76. Heiss, C.; Dejam, A.; Kleinbongard, P.; Schewe, T.; Sies, H.; Kelm, M. Vascular effects of cocoa rich in flavan-3-ols. JAMA 2003, 290, 1030-1031. [CrossRef] [PubMed]

77. Heiss, C.; Kleinbongard, P.; Dejam, A.; Perré, S.; Schroeter, H.; Sies, H.; Kelm, M. Acute consumption of flavanol-rich cocoa and the reversal of endothelial dysfunction in smokers. J. Am. Coll. Cardiol. 2005, 46, 1276-1283. [CrossRef] [PubMed]

78. Vlachopoulos, C.; Aznaouridis, K.; Alexopoulos, N.; Economou, E.; Andreadou, I.; Stefanadis, C. Effect of dark chocolate on arterial function in healthy individuals. Am. J. Hypertens. 2005, 18, 785-791. [CrossRef] [PubMed]

79. Njike, V.Y.; Faridi, Z.; Shuval, K.; Dutta, S.; Kay, C.D.; West, S.G.; Kris-Etherton, P.M.; Katz, D.L. Effects of sugar-sweetened and sugar-free cocoa on endothelial function in overweight adults. Int. J. Cardiol. 2011, 149, 83-88. [CrossRef] [PubMed]

80. Heiss, C.; Finis, D.; Kleinbongard, P.; Hoffmann, A.; Rassaf, T.; Kelm, M.; Sies, H. Sustained increase in flow-mediated dilation after daily intake of high-flavanol cocoa drink over 1 week. J. Cardiovasc. Pharmacol. 2007, 49, 74-80. [CrossRef] [PubMed]

81. Balzer, J.; Rassaf, T.; Heiss, C.; Kleinbongard, P.; Lauer, T.; Merx, M.; Heussen, N.; Gross, H.B.; Keen, C.L.; Schroeter, H.; et al. Sustained benefits in vascular function through flavanol-containing cocoa in medicated diabetic patients a double-masked, randomized, controlled trial. J. Am. Coll. Cardiol. 2008, 51, 2141-2149. [CrossRef] [PubMed]

82. Mills, C.E.; Flury, A.; Marmet, C.; Poquet, L.; Rimoldi, S.F.; Sartori, C.; Rexhaj, E.; Brenner, R.; Allemann, Y.; Zimmermann, D.; et al. Mediation of coffee-induced improvements in human vascular function by chlorogenic acids and its metabolites: Two randomized, controlled, crossover intervention trials. Clin. Nutr. 2017, 36, 1520-1529. [CrossRef] [PubMed]

83. Dower, J.I.; Geleijnse, J.M.; Gijsbers, L.; Zock, P.L.; Kromhout, D.; Hollman, P.C. Effects of the pure flavonoids epicatechin and quercetin on vascular function and cardiometabolic health: A randomized, double-blind, placebo-controlled, crossover trial. Am. J. Clin. Nutr. 2015, 101, 914-921. [CrossRef] [PubMed]

84. Heiss, C.; Sansone, R.; Karimi, H.; Krabbe, M.; Schuler, D.; Rodriguez-Mateos, A.; Kraemer, T.; Cortese-Krott, M.M.; Kuhnle, G.G.; Spencer, J.P.; et al. Impact of cocoa flavanol intake on age-dependent vascular stiffness in healthy men: A randomized, controlled, double-masked trial. Age 2015, 37, 9794. [CrossRef] [PubMed]

85. Lamport, D.J.; Pal, D.; Moutsiana, C.; Field, D.T.; Williams, C.M.; Spencer, J.P.; Butler, L.T. The effect of flavanol-rich cocoa on cerebral perfusion in healthy older adults during conscious resting state: A placebo controlled, crossover, acute trial. Psychopharmacology 2015, 232, 3227-3234. [CrossRef] [PubMed]

86. Sorond, F.A.; Lipsitz, L.A.; Hollenberg, N.K.; Fisher, N.D. Cerebral blood flow response to flavanol-rich cocoa in healthy elderly humans. Neuropsychiatr. Dis. Treat. 2008, 4, 433-440. [PubMed]

87. Desjardins, M.B.A.; Desautels, A.; Marquis, L.; Soucy, J.; Montplaisir, J.; Zadra, A. Effects of sleep deprivation on brain perfusion patterns in sleepwalkers' wakefulness and slow wave sleep. J. Sleep Sleep Disord. Res. 2017, 40, A273-A274.

88. Asllani, I.H.C.; Borogovac, A.; Tatarina, O.; Brown, T.R.; Basner, R.C.; Stern, Y. Effects of 48hr sleep deprivation on cerebral blood flow measured with arterial spin labeling MRI. Proc. Intl. Soc. Mag. Reson. 2007, 15, 507.

89. Grolimund, P.; Seiler, R.W. Age dependence of the flow velocity in the basal cerebral-arteries-A transcranial doppler ultrasound study. Ultrasound Med. Biol. 1988, 14, 191-198. [CrossRef]

90. Fabiani, M.; Gordon, B.A.; Maclin, E.L.; Pearson, M.A.; Brumback-Peltz, C.R.; Low, K.A.; McAuley, E.; Sutton, B.P.; Kramer, A.F.; Gratton, G. Neurovascular coupling in normal aging: A combined optical, ERP and fMRI study. Neuroimage 2014, 85, 592-607. [CrossRef] [PubMed] 
91. Viswanathan, A.; Macklin, E.A.; Betensky, R.; Hyman, B.; Smith, E.E.; Blacker, D. The Influence of Vascular Risk Factors and Stroke on Cognition in Late Life: Analysis of the NACC Cohort. Alzheimer Dis. Assoc. Disord. 2015, 29, 287-293. [CrossRef] [PubMed]

92. Fisher, N.D.; Hollenberg, N.K. Aging and vascular responses to flavanol-rich cocoa. J. Hypertens. 2006, 24, 1575-1580. [CrossRef] [PubMed]

93. Moncada, S.; Palmer, R.M.J.; Higgs, E.A. Nitric-oxide-Physiology, pathophysiology, and pharmacology. Pharmacol. Rev. 1991, 43, 109-142. [PubMed]

94. Loke, W.M.; Hodgson, J.M.; Proudfoot, J.M.; McKinley, A.J.; Puddey, I.B.; Croft, K.D. Pure dietary flavonoids quercetin and (-)-epicatechin augment nitric oxide products and reduce endothelin-1 acutely in healthy men. Am. J. Clin. Nutr. 2008, 88, 1018-1025. [CrossRef] [PubMed]

95. Ward, M.R.; Thompson, K.A.; Isaac, K.; Vecchiarelli, J.; Zhang, Q.; Stewart, D.J.; Kutryk, M.J. Nitric oxide synthase gene transfer restores activity of circulating angiogenic cells from patients with coronary artery disease. Mol. Ther. 2011, 19, 1323-1330. [CrossRef] [PubMed]

96. Iadecola, C. Nitric oxide: Roles in neurovascular regulation and ischemic brain injury. Nitric Oxide Biol. Chem. 2012, 27, S3. [CrossRef]

97. Gallo, E.F.; Iadecola, C. Neuronal nitric oxide contributes to neuroplasticity-associated protein expression through cGMP, protein kinase G, and extracellular signal-regulated kinase. J. Neurosci. 2011, 31, 6947-6955. [CrossRef] [PubMed]

98. Okamoto, M.; Etani, H.; Yagita, Y.; Kinoshita, N.; Nukada, T. Diminished reserve for cerebral vasomotor response to L-arginine in the elderly: Evaluation by transcranial Doppler sonography. Gerontology 2001, 47, 131-135. [CrossRef] [PubMed]

99. Kamper, A.M.; Spilt, A.; de Craen, A.J.; van Buchem, M.A.; Westendorp, R.G.; Blauw, G.J. Basal cerebral blood flow is dependent on the nitric oxide pathway in elderly but not in young healthy men. Exp. Gerontol. 2004, 39, 1245-1248. [CrossRef] [PubMed]

100. Toda, N. Age-related changes in endothelial function and blood flow regulation. Pharmacol. Ther. 2012, 133, 159-176. [CrossRef] [PubMed]

101. Lamport, D.J.; Lawton, C.L.; Merat, N.; Jamson, H.; Myrissa, K.; Hofman, D.; Chadwick, H.K.; Quadt, F.; Wightman, J.D.; Dye, L. Concord grape juice, cognitive function, and driving performance: A 12-wk, placebo-controlled, randomized crossover trial in mothers of preteen children. Am. J. Clin. Nutr. 2016, 103, 775-783. [CrossRef] [PubMed]

102. Haskell-Ramsay, C.F.; Stuart, R.C.; Okello, E.J.; Watson, A.W. Cognitive and mood improvements following acute supplementation with purple grape juice in healthy young adults. Eur. J. Nutr. 2017, 56, 2621-2631. [CrossRef] [PubMed]

103. Fisher, N.D.; Hughes, M.; Gerhard-Herman, M.; Hollenberg, N.K. Flavanol-rich cocoa induces nitric-oxide-dependent vasodilation in healthy humans. J. Hypertens. 2003, 21, 2281-2286. [CrossRef] [PubMed]

104. Toda, N.; Nakanishi-Toda, M. How mental stress affects endothelial function. Pflugers Arch. Eur. J. Physiol. 2011, 462, 779-794. [CrossRef] [PubMed]

(C) 2018 by the authors. Licensee MDPI, Basel, Switzerland. This article is an open access article distributed under the terms and conditions of the Creative Commons Attribution (CC BY) license (http://creativecommons.org/licenses/by/4.0/). 